\title{
Determinants of Low Birth Weight in Cilacap District
}

\section{Majestika Septikasari}

School of Health Sciences Al-Irsyad Al-Islamiyyah Cilacap, Central Java

\section{ABSTRACT}

Background: Low birth weight (LBW) is closely related to the increased risk of child morbidity and mortality, disruption of developmental growth and in the long run has an increased risk of chronic disease in their adulthood. This study aims to analyze the effect of nutritional status at the beginning of pregnancy, maternal education and family expenditure on the incidence of low birth weight (LBW) in Cilacap District.

Subjects and Method: This study is an observational analytic study with a cross sectional approach. The study was conducted in three health centers in Cilacap District, Central Java, in 2016. A sample of 144 children aged less than 1 year was selected by cluster sampling. The dependent variable was birth weight. The independent variables were maternal MUAC, maternal education, and family income. The data are collected with medical records. The data were analyzed using multiple logistic regression analysis.

Results: Maternal MUAC $\geq 23.5 \mathrm{~cm}(\mathrm{OR}=0.22$; $95 \% \mathrm{CI}=0.57$ to $0.89 ; \mathrm{p}=0.033$ ) reduced the risk of LBW and it was statistically significant. Maternal education $(\mathrm{OR}=0.51 ; 95 \% \mathrm{CI}=0.12$ to 2.13; $\mathrm{p}=0.356)$ and high family income (OR = $0.47 ; 95 \% \mathrm{CI}=0.09$ to $2.47 ; \mathrm{p}=0.376$ ) reduced the risk of LBW but it is statistically insignificant. Conclusion: Maternal MUAC $\geq 23.5 \mathrm{~cm}$, high maternal education, and high family income reduced the risk of LBW.

Keywords: low birth weight, maternal midupper arm circumference

\section{Correspondence:}

Majestika Septikasari. School of Health Sciences Al-Irsyad Al-Islamiyyah Cilacap, Central Java, Indonesia. Email: majestika86@gmail.com.

Cite this as:

Septikasari M (2020). Determinants of Low Birth Weight in Cilacap District. J Matern Child Health. 5(2): 141146. https://doi.org/10.26911/thejmch.2020.05.02.03

cc (i) (2) Journal of Maternal and Child Health is licensed under a Creative Commons Attribution-Non Commercial-Share Alike 4.o International License.

\section{BACKGROUND}

Low birth weight or often referred to as LBW is closely related to the increased risk of child morbidity and mortality, disruption of developmental growth and in the long run has an increased risk of chronic disease in adulthood. Babies born with LBW are often found to experience problems in the body system that can cause complications such as asphyxia, intracranial bleeding and hypoglycemia (Tavosnanska et al., 2012).

In addition, infants with low birth weight have low immune system which causes more susceptible to infectious diseases (Escalante et al., 2018). This situation causes babies with low birth weight at risk of dying in the perinatal period eight times greater than babies born with normal weight (Kusparlina, 2016). LBW is associated with disruption of child growth and development. The results of research conducted in Cilacap showed that LBW was at greater risk of stunting compared to babies born with normal weight (Septikasari, 2018).

According to the study, child with LBW experience more delays in motor development and ability to solve problems than children without a history of LBW (Karimi et al., 2011). LBW also has a long-term impact, namely the increased risk of chronic diseases in adulthood (Negrato and Gomes, 2013). Based on the study by Alexander et al. (2014), it shows that most chronic diseases such as hypertension, cardiovascular disease 
and type 2 diabetes mellitus are associated with LBW history.

Although the impact of LBW is quite large, the rate of LBW is currently still high. According to WHO, the prevalence of LBW in the world is $15.5 \%$. Nationally, LBW rates in Indonesia reached 6.3\% (Setyo and Paramita 2015). In Cilacap District in 2015, 4.2\% of babies were born with LBW (District Health Office of Cilacap, 2016). The high number of LBW cases was caused by several factors including the nutritional status of pregnant women. According to Janjua et al. (2009), the nutritional status of pregnant women significantly correlates with the birth weight of babies.

Poor nutritional status such as chronic lack of energy conditions (CED) during the pre-pregnancy period can cause obstruction of the growth of the baby in the womb which has an impact on low birth weight. Besides being influenced by the nutritional status of pregnant women, LBW can also be indirectly influenced by maternal education. High maternal education is related to the mother's knowledge and awareness about healthy life, including in fulfilling nutrition during pregnancy. High maternal education can also encourage mothers to routinely carry out antenatal care.

Based on the results of study by Rini and Trisna (2015), mothers who have higher education have a lower risk of giving birth to babies with LBW compared to mothers with low education. In addition, socio-economic factors are also one of the factors that influence the incidence of LBW. Low socio-economic families have the possibility of not being able to meet family nutritional needs properly so they have the risk of having babies with LBW (Rini and Trisna 2015).

This study aims to analyze the effect of nutritional status in pregnancy through the approach of upper arm circumference (MU$\mathrm{AC}$ ), maternal education and socio-economic family through family expenditure approach to the incidence of babies with (LBW).

\section{SUBJECTS AND METHOD}

\section{Study Design}

This was an observational analytic study with a cross sectional approach conducted in Kesugihan and Sampang community health centers, Cilacap, Central Java, in 2016.

\section{Population and Sample}

A sample of 144 children aged less than 1 year was selected for this study by cluster random sampling.

\section{Study Variables}

The dependent variable was low birth weight. The independent variables were maternal MUAC, maternal education, and family income.

\section{Operational Definition of Variables}

Maternal MUAC used for the assessment of nutritional status among mothers. It is a good predictor of mortality and in many studies.

Maternal education was the last formal education taken by the mother. The data was collected using questionnaire.

Family income was the total amount of husband and wife income earned for the type of work done in each month. The data was collected using questionnaire.

\section{Study instrument}

Data on birth weight and maternal MUC obtained from the maternal and child health book. The others data were collected by questionnaire.

\section{Data analysis}

The data were analyzed by a multiple logistic regression.

\section{RESULTS}

The results of the study on the effect of maternal MUAC, maternal education, and family expenditure on LBW showed in Table 1. Based on Table 1, 23.6\% of children were born to mothers with MUAC <23.5 $\mathrm{cm}$. A 
total of $42.4 \%$ mothers were senior high

family with low family income.

school and $56.9 \%$ of children were lived in

Table 1.The distribution of Frequency of Characteristics of Respondents

\begin{tabular}{lcc}
\hline Variable & $\mathbf{n}$ & \% \\
\hline Maternal MUAC & & 23.6 \\
$<23.5 \mathrm{~cm}$ & 34 & 76.4 \\
$\geq 23.5 \mathrm{~cm}$ & 110 & \\
Maternal Education & 2 & 1.4 \\
Not Primary School graduate & 26 & 18.1 \\
Primary School & 45 & 31.3 \\
Junior high school & 61 & 42.4 \\
Senior high school & 10 & 6.9 \\
Bachelor & & \\
Family Income & 82 & 56.9 \\
Low & 62 & 43.1 \\
High & & 6.9 \\
Birth Weight & 10 & 93.1 \\
$<2,500$ g & 134 & \\
$\geq 2,500$ g & & \\
\hline
\end{tabular}

Table 2. The results of logistic regression analysis on the effect of maternal MUAC, maternal education and family outcome on the newborns birth weight

\begin{tabular}{|c|c|c|c|c|}
\hline \multirow[b]{2}{*}{ Independent Variables } & \multirow[b]{2}{*}{$\mathbf{O R}$} & \multicolumn{2}{|c|}{$95 \% \mathrm{CI}$} & \multirow[b]{2}{*}{$\mathbf{p}$} \\
\hline & & $\begin{array}{c}\text { Lower } \\
\text { Limit }\end{array}$ & $\begin{array}{c}\text { Upper } \\
\text { Limit }\end{array}$ & \\
\hline Maternal MUAC $(\geq 23.5 \mathrm{~cm})$ & 0.22 & 0.57 & 0.89 & 0.033 \\
\hline $\begin{array}{l}\text { Maternal Education } \\
\text { ( } \geq \text { Senior high school) }\end{array}$ & 0.51 & 0.12 & 2.13 & 0.356 \\
\hline $\begin{array}{l}\text { Family Income }(\geq \operatorname{Rp} 2,265,000) \\
\text { N Observation }=144 \\
-2 \text { log likedkehood }=64.24 \\
\text { Nagelkerke } R^{2}=14.3 \%\end{array}$ & 0.47 & 0.09 & 2.47 & 0.376 \\
\hline
\end{tabular}

Table 2 showed that maternal MUAC $\geq 23.5$ $\mathrm{cm}(\mathrm{OR}=0.22$; CI 95\%=0.57 to $0.89 ; \mathrm{p}=$ o.033) decreased the risk of LBW and it was statistically significant. High maternal education decreased the risk of LBW, but it was statistically non-significant $(\mathrm{OR}=0.51$; CI $95 \%=0.12$ to $2.13 ; \mathrm{p}=0.356)$. Low family income decreased the risk of LBW, but it was statistically non-significant $(\mathrm{OR}=0.47$; CI $95 \%=0.09$ to $2.47 ; \mathrm{p}=0.376)$.

\section{DISCUSSION}

Pregnant women who were malnourished during pregnancy would have an impact on the size of the placenta which was relatively smaller. This was in line with a study conducted by Winder et al. (2011) which stated that higher maternal fat affected the shape, size and, function of the better placenta. The small size of the placenta would cause the function of the placenta in distributing the nutrients to the fetus to be reduced so that it affected fetal growth which resulted in low birth weight.

Research conducted by Haeussner et al. (2013) showed that placental weight was correlated with newborn weight. The results showed that MUAC in early pregnancy had a 
strong effect on the weight of the babies and it was statistically significant. However, it was different from the existing theory which stated that mothers who experienced CED in early pregnancy would increase the risk of LBW incidents. In this study, mothers who experienced CED in pregnancy were 4.5 times less likely to give birth to babies with LBW than mothers without CED.

This was possible because mothers with CED have been detected early in pregnancy so that mothers have received interventions in the form of dietary arrangements and supplementary food supplements. With the intervention, the maternal weight gain can be pursued to achieve good nutritional status. In addition, weight gain during pregnancy was also one of the factors that affect the weight of the babies. A study done by Karima and Achadi (2012) showed that increasing maternal weight during pregnancy directly affected birth weight.

Maternal education was related to maternal knowledge especially the knowledge about family health. Higher education would also affect a person's perception of behavior. Mothers who have higher education tend to have wider access to information. Mothers who have a high level of education would usually have better knowledge about fulfilling family nutrition including fulfilling nutrition during pregnancy. The results showed that maternal education had a moderate effect on the incidence of LBW.

However, based on the research, mothers who have low level of education reduced the risk of LBW incidence by 1.9 times smaller compared to mothers with high level of education. This could happen because mothers with higher education did not mean that the mothers also have good knowledge in fulfilling nutrition during pregnancy.

This was in accordance with the study of Kartikasari et al. (2012) which stated that maternal nutritional status was not related to maternal education level (Kartikasari et al., 2012). Mothers who were high school graduates did not necessarily know how to fulfill the nutrition of pregnant women compared to mothers who were elementary school graduates. Even though they have low level of education, if the mother wanted to find the information about nutrition, it was not impossible for the mother to have better nutrition knowledge.

The family outcome approach was often used to measure the family's socio-economic conditions because accurate family income data was more difficult to obtain. The high family outcome could show a good family social economic situation. A good family social condition was one of the factors that play a role in fulfilling the nutritional needs of family members including the nutritional needs of pregnant women. Based on research by Khatun and Rahman (2008), family socioeconomic factors significantly affected the incidence of LBW (Khatun and Rahman 2008)

The results showed that family outcome had a moderate effect on LBW incidents, however, it was different from the existing theory where low family outcome would increase LBW risk factors. In this study, it was found that low family outcome could reduce the risk of LBW by 2 times compared to high family outcome. Family outcome did not necessarily indicate the amount of expenditure allocation in the food sector.

A study by Purwaningsih (2014), showed a fairly large proportion of family outcome on cigarette expenditure (Purwaningsih et al. 2014). High family outcome without food security would lead to the inadequate of the nutritional needs of pregnant women. This will increase the risk of LBW. Although the family outcomes were quite low, if the family's nutritional needs can be fulfilled properly, the risk of LBW can be reduced. 
AUTHOR CONTRIBUTION

Majestika Septikasari collected the data, did data analysis, interpreted the results of data analysis, and wrote the manuscript.

\section{CONFLICT OF INTEREST}

I declare that there was no conflict of interest.

\section{FUNDING AND SPONSORSHIP}

There was no external funding.

\section{ACKNOWLEDGEMENT}

The author would like to say thank you to Kesugihan and Sampang community health centers, Cilacap, Central Java. Thank you for allowing this study to be carried out and to all study subjects who were willing and cooperative to be part of this study.

\section{REFERENCE}

Alexander, Barbara T, Dasinger JH, Intapad S (2014). Low birth weight: Impact on women's health. Clinical Therapeutics, 36(12): 1913-23. https://doi.org/10.1016/j.clinthera.2014.06.026

Dinas Kesehatan Kab. Cilacap (2016). Profil Kesehatan Kabupaten Cilacap Tahun 2015. Cilacap. Retrieved from https://www.kemkes.go.id/

Escalante MJ, Ceriani-Cernadas JM, D'Apremont I, Bancalari A, Webb V, Genes L, Villarroel L, Munoz E, Tapia JL (2018). Late onset sepsis in very low birth weight infants in the South American NEOCOSUR Network. Pediatr Infect Dis J.37 (10): 1022-1027. https://doi.org/10.1097/inf.0000000000001958

Haeussner E, Schmitz C, Von Koch F, Frank HG (2013). Birth weight correlates with size but not shape of the normal human placenta. Placenta, 34(7): 574-82. https://doi.org/10.1016/j.placenta.2013.04. 011

Janjua NZ, Delzell E, Larson RR, Meleth S, Kristensen S, Kabagambe E, Sathiakumar $\mathrm{N}$ (2009). Determinants of low birth weight in urban Pakistan. Public Health Nutrition, 12(6):789-98. https://doi.- org/10.1017/s1368980008002942

Karimi M, Fallah R, Dehghanpoor A, Mirzaei M (2011). Developmental status of 5-yearold moderate low birth weight children. Brain \& development. 33(8):651-55. https://doi.org/10.1016/j.braindev.2010. 10.022

Kartikasari BW, Mifbakhuddin, MustikaDN (2012). Hubungan pendidikan, paritas, dan pekerjaan ibu dengan status gizi ibu hamil trimester III di Puskesmas Bangetayu Kecamatan Genuk Kota Semarang Tahun 2011. Jurnal Kebidanan Universitas Muhammadiyah Semarang. 1(1): 112.

Khatun S, Rahman M (2008). Socio-economic determinants of low birth weight in Bangladesh: A multivariate approach. Bangladesh Med Res Counc Bull, 34: 8186. https://doi.org/10.3329/bmrcb.v34i3.1857

Kusparlina EP (2016). Hubungan Antara umur dan status gizi ibu berdasarkan ukuran lingkar lengan atas dengan jenis BBLR. Jurnal Penelitian Kesehatan Suara Forikes. 7(1):21-26.

Negrato CA, Gomes MB (2013). Low birth weight: Causes and consequences. Diabetology \& Metabolic Syndrome 5(49). https://doi.org/10.1186/1758-5996-6-60

Purwaningsih Y, Hartono S, Masyhuri, Mulyo $\mathrm{JH}$ (2014). Pola pengeluaran pangan rumah tangga menurut tingkat ketahanan pangan di Provinsi Jawa Tengah. Universitas Sebelas Maret. Jurnal Ekonomi Pembangunan, 11(2): 236-253 https://doi.org/10.23917/jep.v11i2.327

Rini SS, IGA Trisna W (2015). Faktor - faktor risiko kejadian berat bayi lahir rendah di wilayah kerja unit pelayanan terpadu Kesmas Gianyar II. e-Jurnal Medika Udayana. 4(4). https://ojs.unud.ac.id/index.php/eum/article/view/13057

Septikasari M (2018). Determinants of stunting in Tambakreja Village, South Cilacap District, Cilacap. 27-32 in the International Midwifery Scientific Conference. Retrie- 
ved from https://osf.io/preprints/inarxiv/w8cha

Pramono MS, Paramita S (2015). Pola kejadian dan determinan bayi dengan berat badan lahir rendah (BBLR) di Indonesia. Buletin Penelitian Sistem Kesehatan. 18: 1-10.

Tavosnanska J, Carreras IM, Fariña D, Luchtenberg G, Celadilla ML, Celotto M, Ferreiro N, González J, Grois I (2012). Morbidity and mortality in very low birth weight infants assisted in public hospitals located in the City of Buenos Aires. Archivos Argentinos de Pediatria, 110(5): 394-403.

Winder NR,Winder, Krishnaveni GV, Veena SR, Hill JC, Karat CLS, Thornburg KL, Fall CHD, Barker DJP (2011). Mother's life time nutrition and the size, shape and efficiency of the placenta. Placenta. 32(11): 806-10. https://doi.org/10.1016/j.placenta.2011.09.001 